\title{
DESAIN MESIN BURNER OVEN TEMBAKAU DENGAN BAHAN BAKAR BIOMASSA WOOD PELET
}

\author{
Yodi Prasetyo \\ Program Studi Teknik Mesin \\ Universitas Muria Kudus \\ Email : prasetyoyodi.yp@gmail.com \\ Rianto Wibowo \\ Program Studi Teknik Mesin \\ Universitas Muria Kudus \\ Email : Rianto.wibowo@umk.ac.id \\ Masruki Kabib \\ Program Studi Teknik Mesin \\ Universitas Muria Kudus \\ Email: masruki.kabib@umk.ac.id \\ Qomaruddin \\ Program Studi Teknik Mesin \\ Universitas Muria Kudus \\ Email: qomaruddin@umk.ac.id
}

\begin{abstract}
ABSTRAK
Kualitas tembakau ditentukan oleh proses pengolahannya setelah panen. Salah satu proses yang menentukan adalah proses pengeringan tembakau. Penelitian ini bertujuan untuk mendesain mesin burner oven tembakau dengan bahan bakar biomassa wood pellet. Metode desain diawali dengan proses kajian pustaka, desain mesin dan simulasi tegangan rangka. Tahap awal dalam mendesain mesin burner adalah menghitung jumlah kalor untuk proses pengeringan tembakau, sehingga dapat menentukan kebutuhan energi dari bahan bakar wood pellet yang dibutuhkan, menghitung jumlah udara untuk proses pembakaran. Tahap selanjutnya menghitung jumlah bahan bakar wood pellet untuk menentukan dimensi ruang bakar dan dimensi screw conveyor. Hasil penelitian adalah energi untuk mengeringkan $30 \mathrm{~kg}$ tembakau sebesar 4.395,3 kj dan dibutuhkan total energi panas wood pellet $6.670 \mathrm{~kJ}$. Udara yang diperlukan untuk pembakaran sebesar $1,078 \mathrm{~m}^{3} / \mathrm{jam}$. Sehingga didapat dimensi ruang bakar berdiameter : $105 \mathrm{~mm}$ dan panjang : 180mm. bahan bakar wood pellet yang digunakan sebanyak $0,748 \mathrm{~kg}$ untuk mengeringkan 30 $\mathrm{kg}$ tembakau. Simulasi tegangan frame mesin burner dengan beban beban sebesar 196,1N. Hasil simulasi tegangan equivalent maksimum terjadi dibagian belakang burner sebesar 0,1101Mpa.
\end{abstract}

Kata kunci : burner, biomassa, pembakaran.

\section{ABSTRACT}

The quality of tobacco is determined by the processing after harvest. One of the defining processes is the tobacco drying process. The objective of this research to design a tobacco oven burner machine with wood pellet biomass as fuel. The design method begins with a literature 
review process, machine design and frame stress simulation. The first step is designing the burner machine to calculate the heat for the drying process of tobacco, so that it can determine the wood pellet energy needed, calculating the amount of air for the combustion process. Next step, calculate the amount of wood pellet fuel to determine the dimensions of the combustion chamber and the dimensions of the screw conveyor. The result of research was the energy to dry $30 \mathrm{~kg}$ of tobacco is 4,395.3 $\mathrm{kJ}$ and it takes a total heat energy of wood pellets of 6,670 kJ. The air needed for combustion is $1.078 \mathrm{~m} 3$ / hour. So that we get the dimensions of the combustion chamber diameter: $105 \mathrm{~mm}$ and length: $180 \mathrm{~mm}$. wood pellet fuel that is used is $0.748 \mathrm{~kg}$ or 800 grams to dry $30 \mathrm{~kg}$ of tobacco. The frame simulation is given a load of 196.1N. The maximum stress equivalent simulation results occur on the back of the burner at 0.1101Mpa.

Key words: burner, biomass, combustion

\section{PENDAHULUAN}

Ketergantungan terhadap penggunaan energi tidak terbarukan sangat tinggi ini ditunjukkan dengan meningkatnya jumlah kendaraan bermotor dan juga industri yang mana kebutuhan akan bahan bakar untuk dapat mengoperasikan mesin produksi juga sangat tinggi tidak terkecuali pada kebutuhan bahan bakar fosil, akibatnya ketersediaan akan bahan bakar semakin menipis disamping itu memang jumlah dari ketersediaan bahan bakar itu sendiri memang sangat terbatas [1].

Energi biomassa merupakan salah satu diantara energi terbarukan dalam bentuk energi padat yang berasal dari tumbuhan berlignoselulosa baik yang dapat langsung digunakan atau diproses terlebih dahulu. Biomassa yang dapat dimanfaatkan sebagai sumber energi alternatif salah satunya adalah sisa dari serutan kayu dan sisa proses gergaji [2].

Wood pellet adalah bentuk bahan bakar padat dan ukurannya lebih kecil dari briket yang terbuat dari biomassa yang diproses dengan menggunakan cara tekanan tinggi maupun dengan cara pengempaan. Wood pellet yang digunakan harus memperhatikan faktor-faktor yang menyangkut penggunaan bahan baku biomassa yang akan berpengaruh dari segi pembakaran dengan memperhatikan komposisi bahan baku biomassa. Biomassa tidak harus berasal dari batang kayu, bisa juga dari limbah pertanian yang dikeringkan seperti sekam padi dan jerami [3]. [4]. Penelitian serupa yakni Pengolahan biomassa dari bahan limbah serbuk gergaji diproses dalam bentuk biofuelpellet karena mempertimbangkan kandungan energinya cukup besar, yaitu $4.280 \mathrm{kkal} / \mathrm{kg}$ merupakan pilihan yang tepat sebagai bahan bakar [5].

Mesin merupakan suatu alat untuk memudahkan, membantu, dan mempercepat produksi suatu produk, mesin mampu berkerja lebih karena tingkat ketelitian dan kecepatan dapat diandalkan secara kontinyu [6]. Industri rokok dalam proses memasak bahan baku tembakau memerlukan dryer atau pengering setelah proses casing ini bertujuan supaya didapat suhu dan tingkat kekeringan yang diinginkan. Dryer membutuhkan sumber energi panas yang berasal dari suatu mesin yaitu burner [7]. Burner merupakan bentuk tungku atau kompor yang dinyalakan dengan membakar bahan bakar dan menghasilkan nyala api, desain burner berbentuk silinder horizontal dan menggunakan bahan bakar wood pellet [8]. Screw conveyor diperlukan untuk mentransfer bahan bakar ke ruang bakar, screw conveyor adalah alat untuk memindahkan material yang mempunyai sifat alir dengan cara memutar sudu berbentuk ulir. Simulasi poros screw dibutuhkan untuk mengetahui nilai besar tegangan yang terjadi di poros screw, hasil simulasi juga didapat nilai stress, displacement, dan safety factor [9]. Analisis kekuatan dalam mendesain frame diperlukan untuk mampu mendukung komponen yang lainnya. Analisis tegangan pada frame telah di lakukan pada mesin rol dengan menggunakan metode elemen hingga [10].

Berdasar kebutuhan energi alternatif untuk mesin dryer maka dibutuhkan sebuah teknologi yang dapat mengkonvesi wood pellet menjadi energi panas, desain teknologi yang mana nantinya teknologi tersebut dapat dimanfaatkan sebagai sumber panas untuk mesin pengering tembakau yang baik dan teknologi tersebut adalah mesin burner. 
Tujuan penelitian ini untuk mendesain mesin burner oven tembakau dengan bahan bakar biomassa wood pellet. Diperlukan perhitungan desain untuk menentukan parameter kalor yang di butuhkan untuk ruang oven tembakau.

\section{METODE PENELITIAN}

Tahap proses Desain Mesin Burner Oven Tembakau Dengan Bahan Bakar Biomassa Wood Pellet, Dapat dilihat pada gambar 1 diagram alir di bawah ini. Parameter desain mesin burner dimulai dari 1. Perhitungan kebutuhan kalor tembakau yang akan dikeringkan 2. Perhitungan jumlah kebutuhan bahan bakar wood pellet 3. Perhitungan perencanaan dimensi screw conveyor, meliputi : diameter dan panjang screw, pitch screw, ketebalan daun screw, diameter kopling, ukuran bak, dan ukuran lubang masuk screw. 4. perhitungan poros screw 5. perhitungan bantalan. 6. perhitungan daya motor listrik.

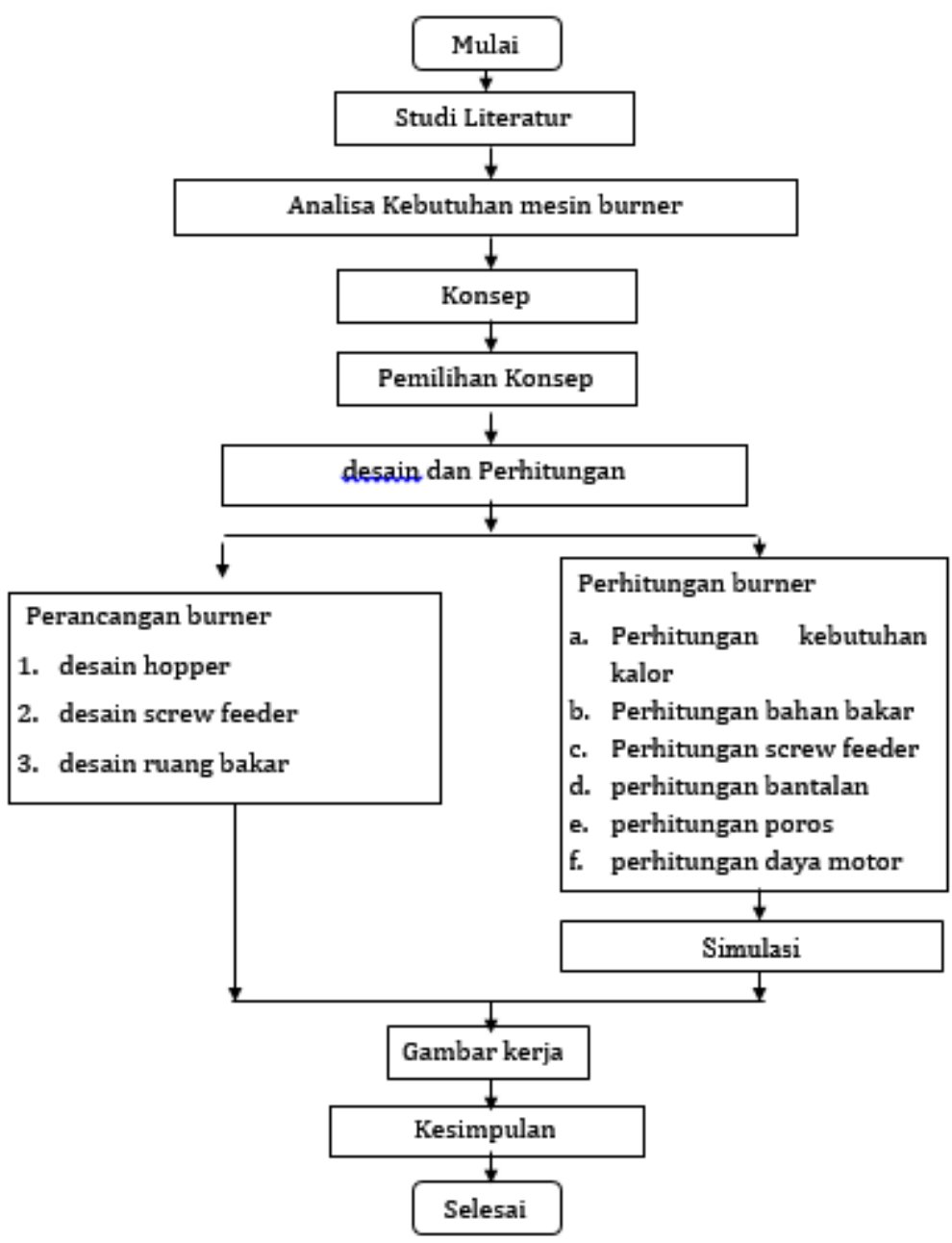

Gambar 2 Diagram alir desain mesin burner 


\section{HASIL PENELITIAN DAN PEMBAHASAN}

Desain Mesin Burner oven tembakau dengan bahan bakar biomassa wood pellet, dapat dilihat pada gambar 2 dibawah ini :

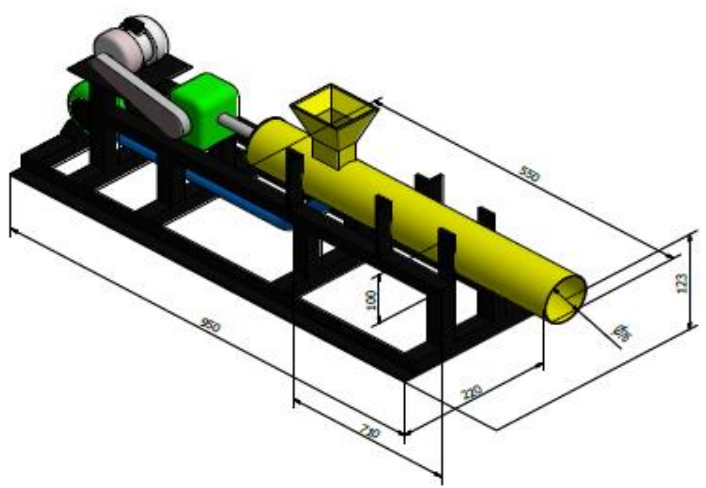

Gambar 2 Desain mesin burner

\section{a. Perhitungan kebutuhan kalor}

Perhitungan kebutuhan kalor dapat dihitung dengan menggunakan persamaan 1 dibawah ini:

$$
q=m \cdot c \cdot \Delta t
$$

Dimana $\mathrm{Q}$ adalah banyaknya kalor yang dibutuhkan (j), $\mathrm{M}$ adalah massa suatu zat yang diberi kalor $(\mathrm{kg})$

$\mathrm{c}$ adalah kalor jenis zat $\left(\mathrm{j} / \mathrm{kg}^{\circ} \mathrm{c}\right), \Delta \mathrm{t}$ adalah perubahan suhu $\left({ }^{\circ} \mathrm{c}\right)$

b. Menghitung jumlah bahan bakar untuk pembakaran wood pellet

Mencari kebutuhan jumlah bahan bakar dapat dihitung menggunakan persamaan 2 dibawah ini :

$$
f c r=\frac{Q n}{H V F X E g}
$$
$\mathrm{kj} / \mathrm{jam}$

Dimana $f c r$ adalah laju konsumsi bahan bakar kg/jam, Qn adalah energi yang diperlukan HVF adalah nilai kalor dari bahan bakar kj/kg, Eg adalah efisiensi gasifier stove( \%).

\section{c. Menghitung dimensi ruang bakar}

Menghitung dimensi ruang bakar dapat dihitung dengan menggunakan persamaan 3 dibawah ini :

Penentuan diameter:

$$
D=\left(\frac{1,27 \cdot f c r}{S G R}\right) \quad 0,5
$$


Dimana D adalah diameter ruang bakar, Fcr adalah fuel consumption rate, SGR adalah specific gasification rate

$$
H=\frac{S G R \cdot T}{\operatorname{Prn}}
$$

Dimana T adalah waktu bahan bakar terbakar secara keseluruhan, Prn adalah densitas bahan bakar

\section{d. Menentukan dimensi screw conveyor}

Screw conveyor terdiri dari poros yang terpasang di screw yang berputar dalam casing (trought) dan penggerak. Screw conveyor berputar secara konstan karena ditopang oleh bantalan (bearing) yang terdapat pada tiap ujung screw. Perputaran screw akan mendorong bahan sepanjang trought (casing). Menghitung kapasitas screw conveyor dapat dihitung menggunakan rumus dibawah ini :

$$
Q=60 \frac{\pi \cdot d^{2}}{4} \sin x \psi \times \mathrm{y} \times \mathrm{c}
$$

Dimana Q adalah Kapasitas screw conveyor (kg/jam), D adalah Diameter screw conveyor $(\mathrm{m}), \mathrm{S}$ adalah Pitch screw conveyor $(\mathrm{m}), \mathrm{n}=$ Putaran screw $(\mathrm{rpm}), \gamma$ adalah Massa jenis material yang dipindahkan $(\mathrm{kg} / \mathrm{m} 3), \psi=$ adalah efisiensi daerah vertical screw conveyor, $\mathrm{C}$ adalah Faktor kemiringan , $\beta$ adalah Sudut kemiringan screw conveyor.

\section{e. Menentukan ukuran poros penggerak}

Desain poros harus mempertimbangkan beberapa faktor diantaranya faktor kekuatan dengan menggunakan pandekatan yield atau fatigue sebagai kriterianya, defleksi, dan juga critical speed dari poros yang akan kita desain.

Pembebanan poros tergantung besaran daya dan putaran mesin yang dihubungkan serta pengaruh gaya yang ditimbulkan oleh bagian mesin yang mendukung dan ikut berputar bersama poros. Beban puntir disebabkan oleh daya dan putaran mesin sedangkan beban lentur serta beban aksial disebabkan oleh gaya radial dan aksial yang timbul.

\section{f. Menentukan bearing}

Perencanaan bearing atau bantalan adalah bagian mesin yang berfungsi sebagai tumpuan poros, supaya putaran atau gerakan poros dapat berputar ditempat dengan baik dan aman, selain itu untuk memperkecil kerugian daya akibat gesekan antar komponen. Bearing harus kuat dan kokoh untuk menahan gaya yang terjadi pada poros. Jika bearing tidak berfungsi dengan baik maka kinerja seluruh bagian akan berpengaruh atau mesin akan hancur karena bertumbukan dengan komponen yang lain. Dalam perencanaan ini akan digunakan jenis bantalan gelinding (roll bearing) karena bantalan ini sangat kuat menerima beban aksial maupun radial yang relatif besar.

\section{g. Menentukan daya motor}

Daya motor dihitung untuk mencari seberapa besar tenaga putar yang dibutuhkan untuk menggerakkan screw atau poros, dapat dihitung menggunakan persamaan dibawah ini :

$$
H=\frac{L(D \text { factor } \cdot n+Q \cdot F)}{1.000 .000}+c
$$

Dimana $\mathrm{L}$ adalah panjang screw (feet), $\mathrm{D}=\mathrm{D}$ faktor, $\mathrm{n}$ adalah putaran screw (rpm), $\mathrm{Q}$ adalah beban yang diangkut kapasitas maksimum (lbs/hr), $\mathrm{F}$ adalah hp material faktor (f), $\mathrm{C}$ adalah faktor inklinasi (1).

Hasil perhitungan desain mesin burner di tunjukkan pada tabel 1. 
Tabel 1. Hasil perhitungan mesin burner

\begin{tabular}{ll}
\hline Nama & Hasil perhitungan \\
\hline Kebutuhan kalor tembakau & $\begin{array}{l}4.395,3 \mathrm{kj} \text { dengan total kalor yang dibutuhkan } \\
6.670 \mathrm{kj}\end{array}$ \\
\hline Kebutuhan bahan bakar & $0,748 \mathrm{~kg} / \mathrm{jam}$ \\
\hline Dimensi ruang bakar & $\mathrm{D}_{\mathrm{b}}=105 \mathrm{~mm}$ dan $\mathrm{H}=180 \mathrm{~mm}$ \\
\hline Jumlah kebutuhan udara pembakaran & $1,078 \mathrm{~m}^{3} / \mathrm{jam}$ \\
\hline Dimensi screw conveyor & $\mathrm{D}_{\mathrm{s}}=101,6 \mathrm{~mm}$ dan panjang $=400 \mathrm{~mm}$ \\
\hline Ukuran poros penggerak & $\mathrm{D}_{\mathrm{p}}=25,4 \mathrm{~mm}$ \\
\hline Daya motor & $\mathrm{P}=1,5 \mathrm{HP}$ \\
\hline
\end{tabular}

\section{f. Simulasi Frame Mesin Burner}

Simulasi frame burner menggunakan software autodesk inventor. Frame mesin burner mendapat beban pada dari poros screw, bantalan, dan motor listrik. Simulasi frame diberikan beban sebesar 196,1N. berikut analisa menggunakan metode elemen hingga.

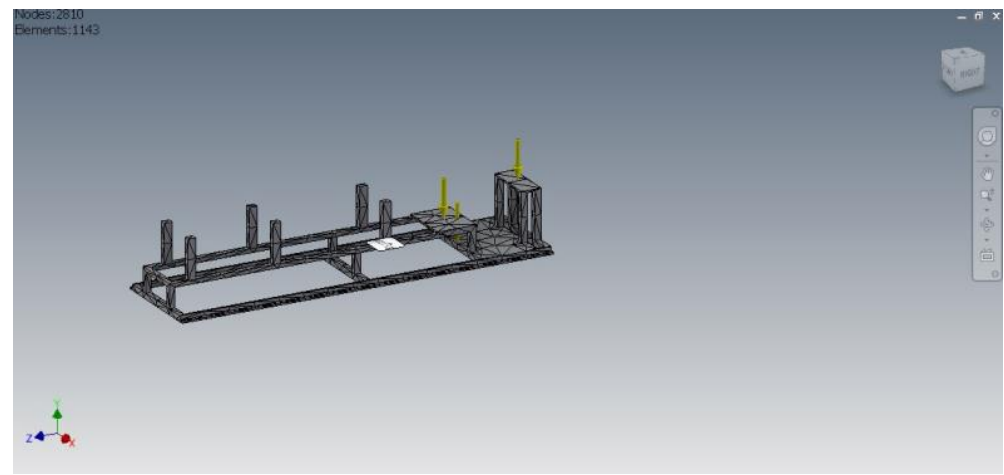

Gambar 3. Frame Mesin Burner

Pengujian pemberian beban pada frame burner dilakukan simulasi pembebanan. Simulasi dilakukan dengan cara memilih environment lalu pilih crate simulate.

1. Hasil analisa von misses stress

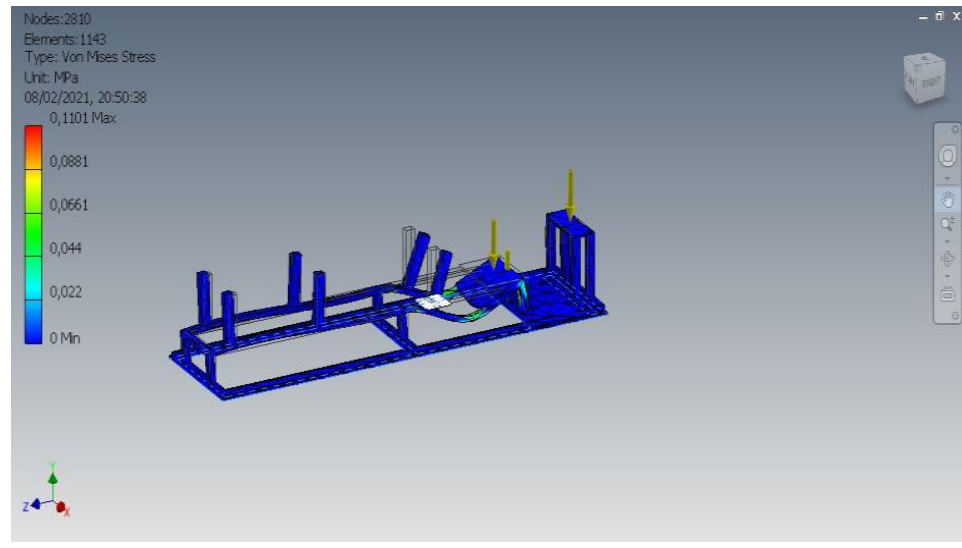

Gambar 4. Simulasi Von misses stres 
Von misses analysis dengan beban 196,1N, tegangan equivalent maksimum terjadi dibagian belakang penyangga burner sebesar 0,1101 Mpa. setelah itu didapat tegangan minimum equivalent sebesar $0 \mathrm{Mpa}$.

2. Hasil safety factor

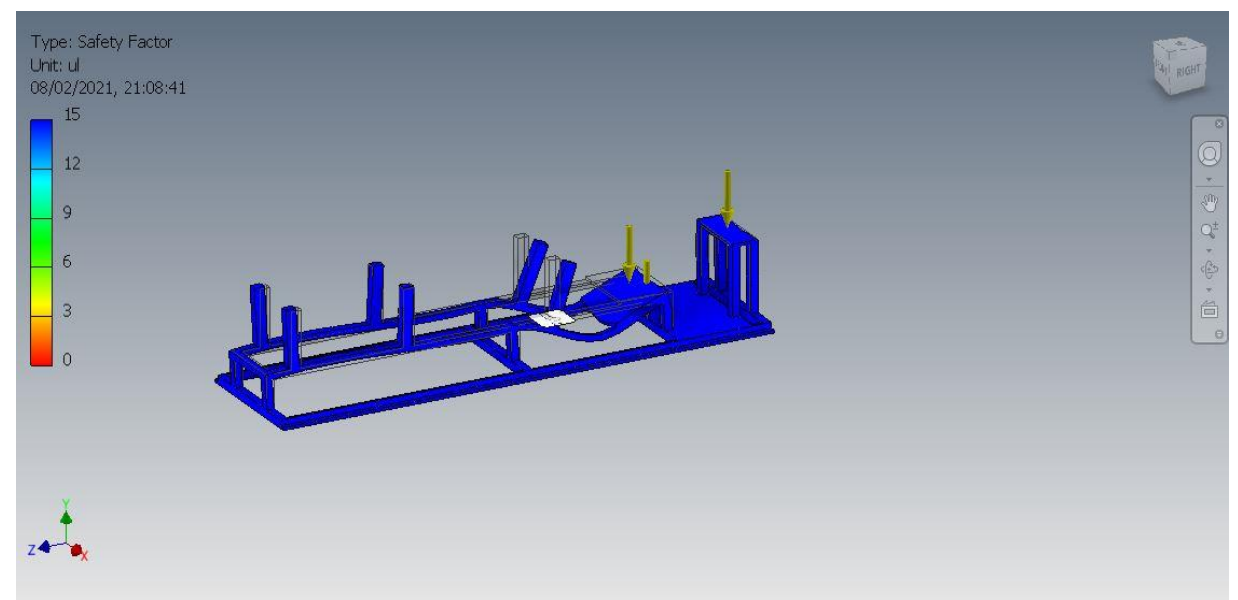

Gambar 5. Safety Factor Frame Burner

Safety factor adalah parameter untuk menentukan suatu konstruksi mesin apakah aman atau tidak. Dan sebagai perbandingan anatara tegangan ijin suatu bahan dengan tegangan yang terjadi.

\section{KESIMPULAN}

Kesimpulan desain mesin burner oven tembakau berbahan bakar biomassa wood pellet didapat kapasitas kalor $6.670 \mathrm{~kJ} /$ jam dari total energi yang dibutuhkan, sehingga didapat jumlah bahan bakar $0,748 \mathrm{~kg} / \mathrm{jam}$ sedangkan kebutuhan jumlah udara untuk pembakaran 1,078m3/jam. kebutuhan bahan bakar tersebut dapat menentukan dimensi mesin yang lain, meliputi : Dimensi ruang bakar didapat diameter $=105 \mathrm{~mm}$ dan panjang $180 \mathrm{~mm}$. Dimensi screw conveyor didapat ukuran dengan diameter $=101,6 \mathrm{~mm}$ dan panjang $400 \mathrm{~mm}$. dimensi poros didapat dengan ukuran diameter : 25,4 $\mathrm{mm}$ dan panjang : $500 \mathrm{~mm}$. motor listrik 1,5 HP kecepatan putaran $1400 \mathrm{rpm}$. Mesin burner oven tembakau dengan bahan bakar biomassa wood pellet berkapasitas kalor $6.670 \mathrm{~kJ} / \mathrm{jam}$ mampu memenuhi kebutuhan kalor untuk mengeringkan tembakau $30 \mathrm{~kg} / \mathrm{jam}$.

\section{DAFTAR PUSTAKA}

[1] Nurlela, 2017 "Desain Dan Uji Kinerja Tungku Pembakaran Tempurung Kelapa Untuk Combined Heat And Power," .

[2] M. Sucipta, and I. N. Suprapta, 2015 "Perancangan Gasifikasi Downdraft dengan Variasi Laju Aliran Oksigen sebagai Agen Gasifikasi," vol. 1, no. 2, pp. 1-8.

[3] Syaifudin zuhri, 2017, "Perancangan Kompor Biomassa Berbahan Bakar Tongkol Jagung" jurnal Simki-Techsain, vol. 01, no. 04, pp. 1-7,

[4] Mohammad I. Fermi, 2014, "Pemanfaatan Metode Computational Fluid Dynamics (CFD) Dalam Perancangan Kompor Biomassa," Teknobiologi, vol. 1, no. February 2014, pp. 1519 ,

[5] E. Lestari, , P. Sarjana, 2009 “Untuk Masyarakat Perkotaan Di Indonesia,” Program Studi Teknik Mesin Universitas Indonesia.

[6] B. Irwanto, M. Kabib, R. Winarso, "Rancang Bangun Sistem Kontrol Penimbangan 
Tembakau Dengan Mikrokontroller Arduino Uno," Jurnal Crankshaft, vol. 2, no. 2, 2019, doi: 10.24176/crankshaft.v2i2.3837.

[7] W. Wiriaatmadja, M. Kabib, T. Hidayat, "Rancang Bangun Mesin Pengisian Curah Tembakau Ke Dalam Bin," Jurnal Crankshaft, vol. 2, no. 2, 2019, doi: 10.24176/crankshaft.v2i2.3862.

[8] M.R. Khiyon, M.S. Zakaria, N.H. Bakar, F. A. Zakaria, 2015 "Design and Development of Flame Burner," 2nd Integrated Design Project Conference (IDPC), 11 Desemer, pp. 0-13,

[9] A. Rofeg, M. Kabib, "Analisa Tegangan Screw Conveyor Pada Mesin Pencampur Garam Dan Iodium Sesuai SNI 3556 Dengan Metode Elemen Hingga," Simetris J. Tek. Mesin, Elektro dan Ilmu Komput., vol. 9, no. 2, pp. 935-940, 2018, doi: 10.24176/simet.v9i2.2452.

[10] S. Kuntoro, M. Kabib, 2018, Analisis Kekuatan Dies Frame Link Pada Mesin Roll Pipa 2 In Penggerak Hidrolik Dengan Metode Elemen Hingga, Jurnal Simetris, Volume 9, Nomor 2, pp. $941-946$. 